INTERnational JOURNAL OF MULtidisciplinaRy Research AND ANALysis

ISSN(print): 2643-9840, ISSN(online): 2643-9875

Volume 03 Issue 12 December 2020

DOI: 10.47191/ijmra/v3-i12-11, Impact Factor: 5.522

Page No.- 334-338

\title{
The Role of Religion in Turkish-Uzbek Relations
}

\author{
A. Sh. Sharipov \\ PhD Student, Center on Contemporary History of Academy of Sciences of Uzbekistan, Tashkent, \\ Uzbekistan
}

\begin{abstract}
This article analyzes the role and place of religion in Uzbek-Turkish relations. In both countries, the Sunni sect of Islam is predominant. In Uzbekistan, religion is separated from the state, and religious activity is fully controlled by the state. The ruling party in Turkey makes extensive use of Islamic elements in governing. Mirziyoyev's rise to power in Uzbekistan marked the beginning of religious cooperation. In Uzbekistan, where religious control has been strong for many years, various forms of religious education, such as Islamic finance and foundation work, have been inactive. Today, after Saudi Arabia and Iran, Turkey claims to be a leader in the Islamic world. The extent to which Turkey's experience in religion and state relations is relevant to Uzbekistan is important.
\end{abstract}

\section{INTRODUCTION}

Islam spread to Central Asia earlier than Turkey in the 8th century AD. Well-known scholars [11] for the Islamic world have emerged in Central Asia. Islamic culture influenced the Turkic peoples living in the region and created a unique culture. The Turkic peoples, who absorbed this Islamic culture, later settled in Asia Minor and made a great contribution to the development of Islamic culture. Today, the achievements of Islam in Central and Asia Minor are recognized throughout the Muslim world. Uzbekistan and Turkey have the largest Sunni populations.

According to the last census in 1989, 93\% of Uzbekistan's population was Sunni Hanafi [1]. As of 2019, there are a total of 2,066 mosques [2] in Uzbekistan. This is low for Uzbekistan, Central Asia's most populous country of more than 33.5 million people. There are 2,691 mosques [3] in Kazakhstan, which has a population of about 19 million.

The Islamic factor plays a special role in the cultural ties between Uzbekistan and Turkey. This factor has its influence and place in various spheres of society. In the 1990s, Turkey tried to use the Islamic factor directly in various areas of cooperation. Since the beginning of liberal reforms in Uzbekistan in 2016, Turkey has intensified relations with Uzbekistan in all areas of cooperation. In particular, about religious cooperation.

\section{MAIN FINDINGS AND RESULTS}

After the independence of the peoples of Central Asia, who lived in the ideology of atheism for 70 years, the task was to choose the appropriate ideological model for the development of Islamic ideology. The Islamic model of Iran, Saudi Arabia and Turkey was in the competition. This option would not be acceptable against the background of theocratic rule and Shiite factors in Iran and the fact that Iran is considered a center of fundamentalism and terrorism in the West. In addition, Iran's use of the Islamic opposition in the civil war in Tajikistan (1992-1997) has caused concern among governments in the region.

In the 1990s, religious missionaries from Saudi Arabia began their activities in the fields of mosques, madrassas, and religious publishing. However, their activities were banned by the Uzbek government in 1993 in an attempt to pit the country's citizens against the constitutional order, the clergy against the state's political elite, and to spread Wahhabi ideas.

There were also concerns that the Turkish model was appropriate for Uzbekistan due to its ethnic and linguistic proximity, cultural closeness, the separation of religion from the state, and the Ahl as-Sunnah Hanafi sect. Turkey's closest allies, the United States and Europe, have also welcomed Turkey's activism in the region [4].

In the 90 s of the last century, there were more than 65 Turkish educational centers in Uzbekistan [4]. All of these educational institutions are controlled by Fethullah Gülen's "Hizmet" organization. 


\section{The Role of Religion in Turkish-Uzbek Relations}

In 1996, the Islamic Refah (Welfare) Party, led by N. Erbakan, came to power in Turkey. At that time, more than 100 Uzbek students were studying at universities in Turkey. Fearing radicalization of Uzbek students studying in Turkey, the Uzbek government deported all students [4].

The closure of Uzbek-Turkish lyceums and schools in the late 1990s was interpreted by the Uzbek government as a violation of Article 7 of the Law on Freedom of Conscience and Religious Organizations [5] and Article 216 of the Criminal Code [6]. The government of Uzbekistan was forced to take action against the use of religious literature in educational institutions opened in cooperation with Turkey, as well as religious propaganda with students. In addition, the involvement of Turkish politician Najmiddin Erbakan in financing the assassination of President Islam Karimov in Tashkent on February 16, 1999, the asylum of terrorists in Turkey, and the cooling of Uzbek-Turkish relations. In order to improve relations, in the early 2000 s, during the visit of Turkish President Ahmet Necdet Sezer to Uzbekistan, an agreement was reached on the "fight against terrorism."

Political Islam became more active in Turkey in the 1990s. In 2002, Erdogan's Islamic Liberal Party came to power. Prior to that, it was the "Millet" Party that operated in Turkey from 1945 to 1950 and was the first to demonstrate political Islam. After that, political organizations such as the "Milli Nizam" Party and the "Milli Selamet" Party operated on the basis of Islamic elements. 1994 was the first election victory of political Islam. As a result of the propaganda, the Refah (Welfare) Party, led by Najmiddin Erbakan, came to power. But his career did not last long. In 1997, he was acquitted by the Constitutional Court on charges of "contrary to the principles of secularism, against Ataturk's revolutionary ideas." The "Fazilet" (Virtue) Party was formed on the basis of the Refah (Welfare) Party. The party also closed in 1999. In 2002, the Justice and Development Party, formed by Erdogan's close ally Recep Tayyip Erdogan, won the parliamentary elections by a wide margin. To this day, the party has ruled Turkey with its liberal Islamic views [8]. The political-Islamic liberal movement, which began in 1994, paid off in 2002. Erdogan sees his party as a Western-style democratic party. They say that this system in Turkey, which combines Islamic values with the appearance of modern democracy as a major achievement, can serve as a model for other Islamic countries.

Due to the events in Andijan in May 2005, [7] official Tashkent did not like Turkey's signing of the UN Human Rights Report in Uzbekistan. The Turkish side also condemned the restriction of religious freedom and strong control over believers in Uzbekistan. Against this background, there were speculations that the Green Revolution would take place in Uzbekistan, that radical Islamic groups would become more active in the Fergana Valley, and that the Akromiya group, a branch of Hizb ut-Tahrir, would intensify its struggle against the regime [8]. The 2000s were marked by stagnation in Uzbek-Turkish relations. In addition, during Islam Karimov's presidency, the West accused Uzbekistan of violating religious freedoms.

Under the 1998 International Religious Freedom Act, Uzbekistan was included in the US State Department's list of countries of "particular concern for violations of freedom of conscience and religion" in 2006. On February 29, 2016, the US State Department re-included Uzbekistan in the list, but it was temporarily removed from the list of temporary sanctions due to US interests and reforms in Uzbekistan [9].

However, in 2017, the US State Department included Uzbekistan in a list of 10 countries "of particular concern due to violations of freedom of conscience and religious freedom." This situation was met with protest by the Committee for Religious Affairs of Uzbekistan [10]. On December 7, 2020, following a change in the religious situation, US Secretary of State Mark Pompeo officially announced that Uzbekistan had been removed from the list.

In 2018, the UN Special Rapporteur on Freedom of Religion or Belief, Ahmad Shahid, reviewed the situation in Uzbekistan and said in his report to the 37th session of the Human Rights Council in Geneva that "religious freedom is regulated by the state and is not recognized in law and practice." The Uzbek side called the report unfair [12]. The Uzbek government has acknowledged that the situation has improved under President Shavkat Mirziyoyev following changes in religion.

In recent years, Turkey has praised the work done in Uzbekistan in the field of freedom of conscience and religion. In particular, human rights have been strengthened, 16,000 people have been removed from the list of people with links to "extremist religious groups" and mosques have been allowed to use the loudspeaker for the call to prayer after a 10-year ban [13].

Speaking at the 72nd session of the UN General Assembly, Shavkat Mirziyoyev stressed that the most important task is to convey the true human nature of Islam to the world community. The great scholars, in particular, said that in order to preserve and study the great scientific heritage of Imam Bukhari, to spread the teachings of enlightened Islam, the International Research Center named after Imam Bukhari is being established in Samarkand and the Center of Islamic Civilization in Tashkent. The President of the Republic of Turkey Recep Tayyip Erdoğan said that no other head of state has ever defended the values of Islam so boldly from the UN rostrum and never mentioned the name of Imam Bukhari [14][18].

Uzbekistan and Turkey share a common vision of Islam and strengthen cooperation at various meetings and gatherings on religion. A few years ago, Quran reciters from Uzbekistan participated in Quran competitions in other Muslim countries. Our selected young people have also participated in the Qori competition held in Turkey several times. On September 1, 2017, during 


\section{The Role of Religion in Turkish-Uzbek Relations}

a visit to the Hazrati Imam Complex, President Shavkat Mirziyoyev proposed to hold a Quran competition in Uzbekistan [15]. In 2018, more than 3,000 people took part in the Quran competition.

In the context of globalization, the President of the Republic of Uzbekistan Shavkat Mirziyoyev emphasized the importance of cooperation between Uzbekistan and Turkey in combating the spread of misconceptions such as Islamophobia in the West in October 2017 during a meeting with Turkish Minister of Religious Affairs Dr. Ali Erbash. President Mirziyoyev stressed the need for proper religious education in order to prevent Muslims from joining radical Islamic groups such as ISIS, Boko Haram, Al-Shabab and FETO [16].

In April 2018, during the official visit of Turkish President Recep Tayyip Erdogan to Uzbekistan, the Turkish Minister of Religious Affairs Dr. Ali Erbash met with Chairman of the Tourism Development Committee of Uzbekistan Aziz Abdukhakimov. During the meeting, the two sides established cooperation in studying the historical heritage of scholars who have contributed to the development of the Islamic world and increasing the number of pilgrims to the holy sites. In addition, the support of the Turkish TIKA Agency in the reconstruction and restoration of mausoleums and shrines of famous scholars and saints in the Islamic world and in our country can be recognized [19].

In the field of religious education, a memorandum of cooperation was signed on June 3, 2018 with the Mir Arab Higher Religious School in Bukhara and Ibn Khaldun, Istanbul Zaim, Kastamonu, Istanbul Universities of Turkey [19]. It should be noted that there are 9 secondary special and 2 higher religious education institutions in Uzbekistan.

The first international forum on international pilgrimage tourism was held on February 21-23, 2019 in Bukhara. The forum was also attended by a Turkish delegation with rich experience in pilgrimage tourism. For information, the Naqshbandi and Moturudi sects are widespread in Turkey, and thousands of its members visit Uzbekistan to visit.

In the attempted coup d'etat in Turkey on June 15, 2016, the involvement of Fethullah Gülen, the leader of the Nurist movement, who identified himself as a follower of Imam Said Nursi, was revealed. At the 43rd session of the Council of Foreign Ministers of the Organization of Islamic Cooperation in October 2016 in Tashkent, the member states declared FETO a "terrorist organization" [20]. Turkish Foreign Minister Mevlut Cavusoglu thanked the member states for their support in Turkey's fight against FETO.

In 2018, Turkish Ambassador to Uzbekistan Ahmet Bashar Shen said on the Day of Remembrance of the more than 200 people killed in the July 15 events, "our country, Uzbekistan, was the first to be aware of the FETO threat and was the first brotherly country to fight their activities" [21]. Many years ago, Uzbekistan banned FETO.

The ideology of FETO was to spread foreign vices, such as seizing public administration, opposing the constitution, and mainly instilling the idea of enlightenment in the minds of the younger generation [22].

Religious cooperation between Uzbekistan and Turkey will affect the image of the two countries in the Islamic world and the fight against religious tolerance, extremism and bigotry, the study of the scientific heritage of scholars who have served Islam for many years [25], religious cooperation within international organizations will continue.

President Mirziyoyev, who took part in the first summit of the Organization of Islamic Cooperation on Science and Technology in Astana, Kazakhstan, on September 7-11, 2017, said that Muslim countries are lagging behind in science [23].

The Organization of Islamic Cooperation's structure for science, education and culture (ISESCO) has declared Bukhara the "Capital of Islamic Culture" [24] in 2020. President Mirziyoyev proposed to hold the second summit of the Organization of Islamic Cooperation on Science and Technology in Bukhara. Following the intensification of its policy in the region, Uzbekistan is promoting its proposals and initiatives in many international organizations. In particular, Turkey welcomed Uzbekistan's accession to the Turkish Council in 2018. It is known that Turkey is interested in accelerating the Turkish integration process.

Islam differs from Western-type financial transactions in that it focuses on financial issues. Uzbekistan is no exception in terms of Islamic finance. In particular, the Islamic Development Bank [26] has been financing various projects in Uzbekistan. For information, Uzbekistan became a member of this financial institution in 1991 at the invitation of Turkey.

During his official visit to Uzbekistan on April 29, 2018, Turkish President Erdogan said that he had discussed with his counterpart Mirziyoyev and they are reached an agreement to launch of the Imam al-Bukhari International Research Center and the Moturudi Center for Islamic Studies [27].

The common position of Uzbekistan and Turkey in important events in the Islamic world also shows that they play a role of solidarity in solving the problems facing Muslims around the world. On May 18, 2018, Turkey convened an extraordinary summit of the Organization of Islamic Cooperation in Istanbul in connection with the incidents on the border with the Gaza Strip [28]. Muslim countries have not been indifferent to the deaths of many people in the unrest in the Gaza Strip after the relocation of the U.S. embassy in Israel from Tel Aviv to Jerusalem. At the summit, the Uzbek delegation unanimously supported the fact that East Jerusalem is the capital of Palestine. Turkey also considers it important for the use of Turkic-speaking countries in the Islamic world. 


\section{The Role of Religion in Turkish-Uzbek Relations \\ CONCLUSION}

In the 1990s, the Uzbek government banned Fethullah Gulen's schools and lyceums from conducting religious propaganda. Due to these factors, cooperation between Turkey and Uzbekistan in education, culture and other spheres has stopped. In addition, the Uzbek opposition and other persecuted citizens have sought political asylum in Turkey, which has worsened relations. Relations between the two countries improved with the coming to power of Shavkat Mirziyoyev in Uzbekistan. Not only religious but also educational and cultural ties were revived. Under the auspices of the Turkish government and organizations such as TIKA and TurkSOY, work is underway on religious cooperation in Uzbekistan, the restoration of Islamic holy sites, the study of the scientific heritage of scholars [29] and the organization of Muslim pilgrimage tourism. In addition, cooperation is underway in the organization of Hajj and Umrah, the joint fight against Islamophobia and religious extremism around the world. Cooperation on religion can be considered as a new direction for Uzbekistan and Turkey.

\section{REFERENCES}

1) International Religious Freedom Report for 2018. Uzbekistan. US Department of State. https://www.state.gov/i/drl/rls/irf/religiousfreedom/index.htm\#wrapper

2) How many mosques were opened in Uzbekistan in 2019? / (05.01.2020) http://muslim.uz/index.php/yangiliklar2016/uzbekistan/item/18250-2019-jilda-zbekistonda-nechta-maszhid-ochildi

3) In 2019, 80 mosques were opened / (21.01.2020) https://www.muftyat.kz/ru/news/amdb/2019-12-26/29793-v-2019godu-otkrylis-80-mechetei-foto/

4) Türk Dünyasının dini Meseleleri. Türkiye Diyanet Vakfı yayınları.Ankara. 1998. /266/ http://ktp.isam.org.tr/pdfdrg/D118311/1998/1998 ERSAHINS.pdf

5) Law of the Republic of Uzbekistan on Freedom of Conscience and Religious Organizations. http://www.lex.uz/acts/65108

6) Criminal Code of the Republic of Uzbekistan. http://lex.uz/docs/111453

7) https://daryo.uz/k/2017/05/19/andijon-voqealari-haqidagi-afsonalar-qanday-toqilgan

8) Dr. Sinan Oğan. Özbekistan'da "Yeşil” Devrim Sancıları / http://turksam.org/ozbekistan-da-yesil-devrim-sancilari

9) https://uz.usembassy.gov/ru/2015-international-religious-freedom-report-ru/

10) https://azon.uz/content/views/uzbekiston-din-ishlari-buyicha-qumitasi

11) Khudoyberdiyevich, D. A., \& Rakhmonkulovich, N. K. (2018). The contribution of sarah sviri to the study of the scientific heritage of hakim tirmidhi. ACADEMICIA: An International Multidisciplinary Research Journal, 8(11), 60-67. https://www.bbc.com/uzbek/uzbekistan-43302033

12) Özbekistan'da insan hakları alanında büyük adım. Prof. Dr. Alaeddin Yalçinkaya https://www.oncevatan.com.tr/ozbekistan-turk-dunyasinin-yukselen-yildizi-makale,41849.html

13) https://kun.uz/59072222?q $=\% 2 F 59072222$

14) http://uza.uz/uz/society/qur-on-musobaqasida-kim-g-olib-bo-ldi-24-04-2018

15) https://diyanet.gov.tr/fr-FR/Institutionnel/d\%C3\%A9tail/10949/diyanet-isleri-baskani-erbas-ozbekistancumhurbaskani-mirziyoyev-ile-gorustu

16) http://muslim.uz/index.php/vangiliklar-2016/uzbekistan/item/12248

17) КарИМОВ, Н. Р. (2017). НАУЧНОЕ НАСЛЕДИЕ ХАКИМА ТИРМИЗИ И ИССЛЕДОВАНИЯ ЕГО ТРУДА" ХАТМ-УЛАУЛИЯ"(“ПЕЧАТЬ ДРУЗЕЙ БОЖЬИХ”). In EUROPEAN RESEARCH (pp. 24-27).

18) Memorandums of cooperation have been signed between 4 prestigious Turkish universities and Mir Arab High School. / http://www.mir-arab.uz/ruknlar/99

19) FETO has been declared a "terrorist organization" in the Uzbek capital, Tashkent. 20.10.2016 26.02.2019.

20) http://www.trt.net.tr/uzbek/turk-dunyosi/2016/10/20/feto-o-zbekiston-poytaxti-toshkentda-terror-tashkiloti-deb-elon-qilindi-593297

21) Ahmet Başar ŞEN. 15 Temmuz Demokrasi ve Milli Birlik Günü konuşması. 15.07.2018. http://tashkent.emb.mfa.gov.tr/Mission/ShowSpeech/12389

22) Turkish media widely cover the fact that Uzbekistan was the first to realize the true face of Fethullah Gülen. 23 june 2017./ https://vodiymedia.uz/content/124/turk matbuoti fietullagiulienning asl basharasini ilk anglagan zbiekiston ekanini kieng ioritmoda.html

23) President of the Republic of Uzbekistan Sh. Mirziyoyev's speech at the first summit of the Organization of Islamic Cooperation on science and technology. (20.01.2020) http://uza.uz/oz/politics/zbekiston-respublikasi-prezidentishavkat-mirziyeevning-islo-10-09-2017

24) https://www.icesco.org/en/2019/12/18/cairo-proclaimed-as-arab-regions-capital-of-islamic-culture-for-2020/ 


\section{The Role of Religion in Turkish-Uzbek Relations}

25) Хайдаров, И. М., \& Каримов, Н. Р. (2017). CLASSIFICATION OF THE SCIENTIFIC HERITAGE OF HAKIM TIRMIDHI. In EUROPEAN RESEARCH (pp. 28-31).

26) The Islamic Development Bank has been operating since 1975. Uzbekistan has a $0.3 \%$ share in the charter capital of the organization. Turkey has a share of $6.45 \%$. https://www.isdb.org/isdb-member-countries

27) The President of Turkey has arrived in Uzbekistan on a state visit. / (20.01.2020) https://www.trt.net.tr/uzbek/turk-dunyosi/2018/04/30/turkiya-prezidenti-davlat-tashrifi-bilan-o-zbekistonga-keldi$\underline{960953}$

28) Uzbekistan will take part in a special summit of the OIC. (20.01.2020) https://www.gazeta.uz/uz/2018/05/17/iht/

29) Doniyorov, A. K., \& Karimov, N. R. (2019). -KITAB AL-HIKMAH AND-HIKMAH IN HAKIM TIRMIDHI 'S SCIENTIFIC HERITAGE. Central Asian Problems of Modern Science and Education, 4(2), 236-246. 